\title{
МАТЕМАТИЧНА МОДЕЛЬ НАПІВПРОВІДНИКОВОГО ПЕРЕТВОРЮВАЧА ТРИФАЗНӦ̈ НАПРУГИ З ДВАНАДЦЯТИЗОННИМ РЕГУЛЮВАННЯМ ВИХІДНОї НАПРУГИ
}

\begin{abstract}
Анотація: У статті проведено аналіз електромагнітних процесів в електричних колах з напівпровідниковими комутаторами. Створено математичну модель для аналізу електромагнітних процесів у напівпровідникових перетворювачах з широтно-імпульсним регулюванням вихідної напруги. Наведено графіки, що відображають електромагнітні процеси у електричних колах.

Ключові слова: електромагнітні процеси, вихідні напруга та струм.
\end{abstract}

\section{Вступ}

Якісне перетворення електричної енергії дозволяюе використовувати в перетворювальних установках ланку високої частоти з частотою переключення вентилів значно більшої від частоти змінної напруги промислової мережі. У роботах [1-6] показана доцільність використання структур напівпровідникових перетворювачів (НПП) з однократною модуляцією при побудові систем вторинного електропостачання для комплексів діагностики електромеханічних пристроїв із різноманітним видом вхідної енергії. У даній роботі проводиться аналіз аспекту використання тієї ж структури НПП в якості ланки високої частоти, що стосуеться побудови й аналізу перетворювачів для електромеханічних комплексів із широтно-імпульсним регулюванням (ШІР) постійної напруги при дванадцятизонному керуванні.

Метою роботи $є$ використання методу багатопараметричних фрункцій для дослідження електромагнітних процесів в електричних колах з напівпровідниковими комутаторами.

\section{Аналіз електромагнітних процесів}

Узагальнена структурна схема перетворювача показана на pис. 1 . На структурній схемі позначені: $\mathrm{CM} A, \mathrm{CM} B, \mathrm{CM} C$ - силові модулятори (CM) фразних напруг $A, B$ і $C$ відповідно, $\mathrm{BB}$ - високочастотний випрямляч, $\mathrm{H}$ - навантаження. Сукупність СМ, підключених до енергетичної мережі паралельно і з'єднаних по виходу послідовно, представляе собою ланку високої частоти перетворювача. До складу CM входять: інвертори випрямленої напруги (IBH), - узгоджувальні трансформатори (T).

Таким чином кожен $\mathrm{CM}$ має в своєму складі $N \mathrm{IBH}$, де $N$ - це число інверторів.

Створення математичної моделі перетворювача передбачає розробку математичного забезпечення, спроможного провести аналіз

(c) В.В. Михайленко, 2015 


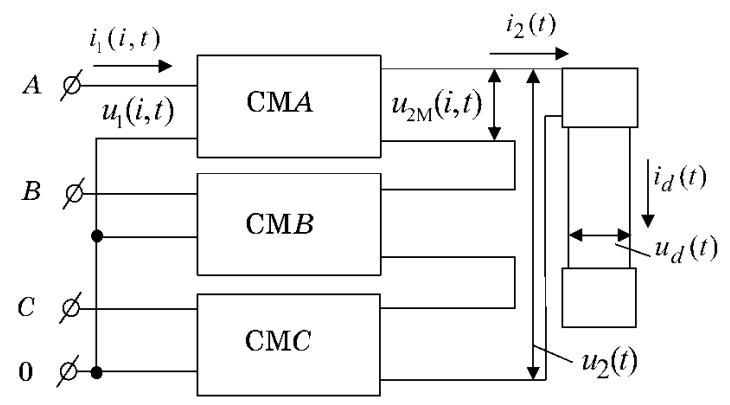

Рис. 1 - Структурна схема перетворювача

його електромагнітних процесів відносно енергії, яка генерується, з урахуванням характеру навантаження, енергії, яка при цьому споживається, а також енергії, яка перетворюеться в окремих ланках і в окремими елементами перетворювача.

При складанні математичної моделі перетворювача із комп'ютерною орієнтацією їі застосування використаємо метод багатопараметрчних модулюючих функцій [1-4], який передбачає попередне представлення алгоритмічного рівняння перетворювача. При цьому приймемо такі припущення: вхідна енергетична мережа си-

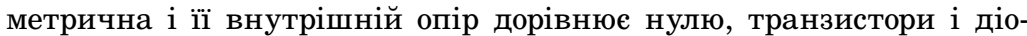
ди IBH представляються ідеальними ключами, узгоджувальні трансформатори не мають втрат, а навантаження перетворювача має еквівалентний активно-індуктивний характер.

Дана структура дозволяе реалізувати багатоканальний спосіб перетворення параметрів електромагнітної енергії мережі, при якому в СМ здійснюеться розгалужена модуляція миттєвих значень попередньо випрямлених фазних напруг $u_{1}(i, t)$, частоти $\omega_{1}$, трифазної енергетичної мережі відповідними еквівалентними модулюючими впливами $\psi\left(\alpha_{P}, t\right)$, частоти $\omega_{2}$. В результаті такої операції на виході кожного з IBH формуеться промодульована напруга

$$
u_{2 M}(p, i, t)=\frac{1}{k_{T}} u_{1}(i, t) \phi(i, t) \psi\left(\alpha_{P}, t\right),
$$

де: $i=1,2,3$ - номери фраз енергетичної мережі; $k_{T}$ - коефіціент трансформації узгоджувального трансформатора; $p=1,2,3, \ldots, n$ - номери зон регулювання вихідної напруги; $\phi(i, t)$ - функції прямокутного сінуса, співпадаючі за часом з положеням відповідних фазних напруг мережі; $u_{1}(i, t)$ - миттеві значення вхідної напруги мережі.

Функції прямокутного сінуса подаються як

$$
\phi(i, t)=\operatorname{sign}\left\{\sin \left(\omega_{1} t-\frac{(i-1) 2 \pi}{3}\right)\right\}
$$


а миттіві значення вхідної напруги мережі представлені у вигляді

$$
u_{1}(i, t)=U_{1 m} \sin \left(\omega_{1} t-\frac{(i-1) 2 \pi}{3}\right),
$$

$U_{1 m}$ - амплітудне значення фразної напруги.

Еквівалентні модулюючі впливи подаються виразом

$$
\psi\left(\alpha_{P}, t\right)=\frac{1}{2} \sum_{2} \operatorname{sign}\left[\sin \left(\omega_{2} t \pm \alpha_{P}(t)-\varphi\right)\right],
$$

де $\alpha_{P}(t)$ - кути управління, за рахунок зміни яких забезпечується ШІР вихідної напруги перетворювача; $\varphi-$ початкова фраза еквівалентних модулюючих впливів;

Вихідна напруга перетворювача $u_{d}(t)$ подається виразом

$$
u_{d}(t)=\frac{1}{k_{T}} \sum_{P=1}^{12} \sum_{i=1}^{3} u_{1}(i, t) \phi(i, t) \psi\left(\alpha_{P}, t\right) v(t),
$$

де $v(t)$ - фрункція прямокутного сінуса, співпадаюча за часом з положенням вихідної напруги $u_{2}(t)$ ланки високої частоти перетворювача.

$$
v(t)=\operatorname{sign}\left(u_{2}(t)\right)
$$

Струм навантаження знайдемо, як реакцію одноконтурного $R L-$ ланцюга на дію напруги (7). Для цього диференціальне рівняння, складене для вихідного контуру перетворювача, представимо у вигляді

$$
D(t, y)=\frac{u_{d}(t)}{L}-\frac{R}{L} y_{0},
$$

де: $y_{0}$ - визначається з початкових умов; $R$ і $L$ - відповідно активний опір і індуктивність навантаження.

Рішення (12) відносно струму навантаження визначимо числовим методом у вигляді матриці

$$
i_{d}(t)=\operatorname{rkfixed}(y, 0, k, s, D),
$$

де: $y$ - вектор початкових умов; $0, k$ - часовий інтервал рішень; $s-$ кількість точок на часовому інтервалі рішень; $D$ - вектор функція диференційних рівнянь .

Еквівалентні моделюючі фрункції (4) і (6), які є безрозмірними і мають одиничну амплітуду, можна розглядати як фрункції перетворення, що визначають залежність вхідного струму від вихідного струму, який показаний у вигляді рішення (8) співвідношенням (7). Для визначення вхідного струму $i_{2}(t)$ високочастотного випрямляча необхідно (7) розділити на (6). Якщо в функції перетворення є нульовий рівень операцію ділення на повному періоді існу- 
вання (8) виконати неможливо. Це призводить до необхідності знаходження струму перед високочастотним випрямлячем на інтервалах ненульового значення, з послідуючим припасовуванням результатів окремих підрахунків. Однак подання (6) функцією одиничної амплітуди дозволяє визначити струм $i_{2}(t)$ перемноженням (8) на (6) i, тим самим, спростити процес підрахунків, представляючи результати на повному інтервалі існування (6) і (8). Таким чином, вхідний струм високочастотного випрямляча має вигляд

$$
i_{2}(t)=i_{d}(t) v(t) .
$$

Для визначення вхідних струмів інверторів $i$-х фраз для кожної $p$-ї зони регулювання врахуємо, що $i_{2}(t)$ протікає в загальному контурі всіх CM, утвореному послідовно з'єднаними вторинними обмотками узгоджувальних трансформаторів і приймемо до уваги алгоритмічне рівняння (9) і те, що (2) і (4) є функціями одиничної амплітуди.

При цьому в загальному виді

$$
i_{1}(n, i, t)=\frac{i_{2}(t) \psi\left(\alpha_{P}, t\right) \phi(i, t)}{k_{T}}
$$

Часові діаграми струму навантаження в координатах вихідної напруги перетворювача, побудовані за (5) - (8) для дванадцятизонного регулювання, представлені на рисунку. 2.

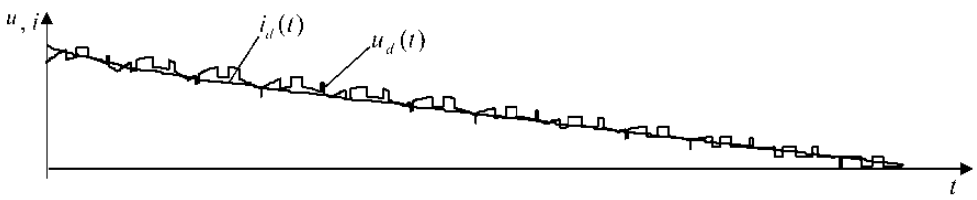

Рис. 2 - Часові діаграми струму і напруги навантаження та вхідних струмів інверторів в координатах фразних напруг енергетичної мережі

Вхідні струми інверторів $i_{1}(n, i, t)$ можуть бути визначені при відомому струму навантаження без попереднього розрахунку вихідного струму $i_{2}(t)$ ланки високої частоти за (10). Для цього треба прийняти до уваги алгоритмічне рівняння (5) і тоді, враховуючи (10), отримаємо

$$
i_{1}(n, i, t)=\frac{i_{d}(t) \phi(i, t)\left|\psi\left(\alpha_{P}, t\right)\right|}{k_{T}} .
$$

Для визначення струмів $i$-х фраз енергетичної мережі у всьому діапазоні регулювання вихідної напруги виконаємо сумування вхідних струмів інверторів всіх зон регулювання в кожній з $i$-й фра- 
зі. Враховуючи рівняння (11) загальний вираз для струмів $i$-х фаз енергетичної мережі подамо у вигляді

$$
i_{1}(i, t)=i_{1}(1, i, t)+i_{1}(2, i, t)+i_{1}(3, i, t)+\ldots+i_{1}(12, i, t)
$$

де: $i_{1}(1, i, t), i_{1}(2, i, t), i_{1}(3, i, t), \ldots, i_{1}(12, i, t)$ - вхідні струми інверторів $i$-х фаз для першої, другої, третьої, та дванадцятої зон регулювання

Часові діаграми вхідних струмів $i-\mathrm{x}$ фаз енергетичної мережі в координатах фразних напруг, побудовані за (12) для трьохзонного регулювання, представлені на рисунку. 3.

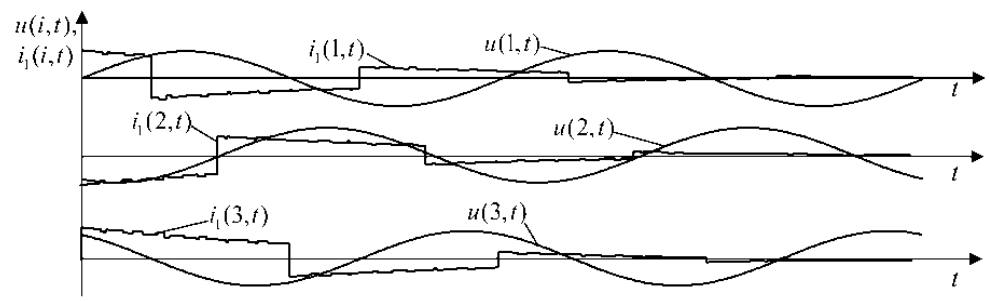

Рис. 3 - Часові діаграми вхідних струмів $i-\mathrm{x}$ фаз енергетичної мережі в координатах фазних напруг

Для того, щоб знайти амплітудні значення струмів через силові транзистори IBH, достатньо проаналізувати струми $i_{1 T}(n, i, t)$ первинних обмоток узгоджувальних трансформаторів, котрі знаходяться в колах протікання струмів через силові транзистори. Враховуючи (9) і число каналів перетворення енергії, отримаємо: $i_{1 T}(n, i, t)=\frac{i_{2}(t)}{12 k_{T}}$. За часом ці струми співпадають з вихідним струмом ланки високої частоти перетворювача.

\section{Список використаних джерел}

1. Макаренко М.П. Математична модель перетворювача трифазної напруги в постійну напругу / М.П. Макаренко, В.В. Михайленко // Электроника и связь. - 2002. - № 14. - С. 73-75.

2. Патент 18750. України. МПК Н02М 1/02. Інвертор напруги / М.П. Макаренко , В.В. Михайленко , В.В. Пілінський, заявник та власник патенту НТУУ “КПІ" - Завл. 31.05.2006, опубл. 15.11.2006. Бюл. № 11.

3. Патент 20985. України. МПК Н02М 1/02. Модулятор випрямленої напруги / М.П. Макаренко, В.В. Михайленко, Заявник та власник патенту НТУУ “КПІ - Завл. 18.09.2006, опубл. 15.02.2007. Бюл. № 2.

4. Макаренко М.П. Системний аналіз електромагнітних процесів у напівпровідникових перетворювачах електроенергії модуля- 
ційного типу / М. П Макаренко, В.І. Сенько, М. М. Юрченко К. : НАН України, ІЕД, 2005. - 241 с.

5. Макаренко М.П. Аналіз електромагнітних процесів у перетворювачах з багатозонним регулюванням вихідної напруги фрункціями багатопараметричного виду / М. П. Макаренко, В. В. Михайленко // Техн. електродинаміка. Тем. вип. "Силова електроніка та енергоефективність". - 2002. - Ч. 1. - С. 19-22.

6. Макаренко Н.П. Анализ электромагнитных процессов в двенадцатипульсном преобразователе с зонным регулированием выходного напряжения / Н. П. Макаренко, В. В. Михайленко, Н. Н. Юрченко // Вестник НТУ "Харьковский политехнический институт". "Проблемы автоматизированного электропривода. Теория и практика". - 2002. - Т. 1. - С. 233-234.

Отримано 23.04.2015 p. 